TECHNICAL TRANSACTIONS 1/2017

CZASOPISMO TECHNICZNE $1 / 2017$

ENVIRONMENTAL ENGINEERING

DOI: $10.4467 / 2353737$ XCT.17.011.6108

\author{
Daniel Venghaus (daniel.venghaus@tu-berlin.de) \\ Matthias Barjenbruch \\ Institute of Civil Engineering, Departement of Urban Water Management, Technische \\ Universität Berlin
}

\title{
MiCROPLASTICS IN URBAN WATER MANAGEMENT
}

MikROPLASTIKI A MIEJSKA GOSPODARKA WODNA

\begin{abstract}
The paper is discussing microplastics in the effluent of wastewater treatment plants and other discharges from urban areas. The aim of the discussion is to expose the challenges related to sampling and detecting plastic particles in treated wastewater. The different types of microplastics and a rough estimation of the amount of plastic which could end up in the aquatic environment is given. The work is based on a literature review of microplastic particles in treated wastewater and discusses their consequences on the aquatic ecosystem.
\end{abstract}

Keywords: microplastic, particle, sample, analytic

\section{Streszczenie}

W artykule omówiono problem obecności mikroplastików w cieczach odplywających z oczyszczalni ścieków i w innych cieczach pochodzących z obszarów miejskich w celu ujawnienia trudności związanych z pobieraniem próbek i wykrywaniem cząsteczek plastiku w ściekach. Określono różne rodzaje mikroplastików oraz szacowaną ilość plastiku, który może znajdować się w środowisku wodnym. Przeprowadzone prace oparto na przeglądzie piśmiennictwa na temat obecności mikrocząsteczek plastiku w ściekach i omówiono jej skutki dla ekosystemu wodnego.

Słowa kluczowe: mikroplastik, cząsteczka, próbka, analiza 


\section{Introduction}

When Charles Goodyear randomly identified the process of vulcanization in 1839 the development of synthetic materials took its course. Later in the 1940's after nylon was introduced, plastics processing was practiced in mass production. [1, 2] In 2014 more than 311 mill. $t$ of plastics where produced worldwide [3]. Germany produced 18.5 mill. $t$ in 2015 out of this amount 12.8 mill. $t$ where exported. Additionally, 9.3 mill. $t$ where imported. This results in an overall plastic consumption of 15 mill. $t$ in Germany. From this amount, 2.94 mill. $t$ where mainly used in branches of gluten, fibers, vanish and 12.06 mill $t$ in branches of packaging (35.2\%), construction (22.7\%) and automotive engineering (10.5\%). Other branches and electronics, agriculture, households medicine and furniture use $31.6 \%$. This consumption results in about 3.7 mill. $t$ of plastic waste in Germany. 53\% of the plastic waste is utilized for energy and $46 \%$ for recycling. About $1 \%$ (0.04 mill. $t)$ ends up on dumpsites [4]. Data on plastic littering is actually not available [5].

\section{Basic Information about plastics}

The most commonly used plastics are polyethylene (PE), polypropylene (PP), polyvinylchloride (PVC), polystyrene (PS) and polyethylenterephthalat (PET), which represent about $90 \%$ of the global plastic production [6]. Table 1 offers a survey of the attributes, the production volume and the possible uses of plastics.

Table 1. Attributes, production volume and the possible uses of plastics [7]

\begin{tabular}{|c|c|c|c|c|}
\hline Sort & Abbreviation & $\begin{array}{c}\text { Density } \\
{\left[\mathrm{g} / \mathrm{cm}^{3}\right]}\end{array}$ & $\begin{array}{c}\% \text { of the } \\
\text { production } \\
\text { volume }\end{array}$ & Possible uses \\
\hline $\begin{array}{c}\text { low-density } \\
\text { polyethylen }\end{array}$ & PE-LD & $0.91-0.93$ & 21 & $\begin{array}{c}\text { carrier bag, straw, } \\
\text { bottle }\end{array}$ \\
\hline $\begin{array}{c}\text { high-density } \\
\text { polyethylen }\end{array}$ & PE-HD & 0.94 & 17 & can, pipe \\
\hline polypropylene & PP & $0.83-0.85$ & 24 & bottle top \\
\hline polystyrene & PS & 1.05 & 6 & $\begin{array}{c}\text { electronic casing, } \\
\text { thermal insulation } \\
\text { material, } \\
\text { packaging }\end{array}$ \\
\hline polyethylenterephthalat & PET & 1.37 & 7 & bottles \\
\hline polyvinyl chloride & PVC & 1.38 & 19 & foil, pipe \\
\hline
\end{tabular}

It is shown that a large part of the produced plastic is used in different products and processes in all different ranges of application. Consequentially one big challenge is to define the pathways of plastics and microplastics which end up in the aquatic environment and to balance them. 


\section{Microplastics}

Beside the subdividing particles in macro- and mesoplastics, the Marine Strategy Framework Directive $(2008 / 56 / \mathrm{EG})$ describes particles $<5 \mathrm{~mm}$ as microplastics [8].

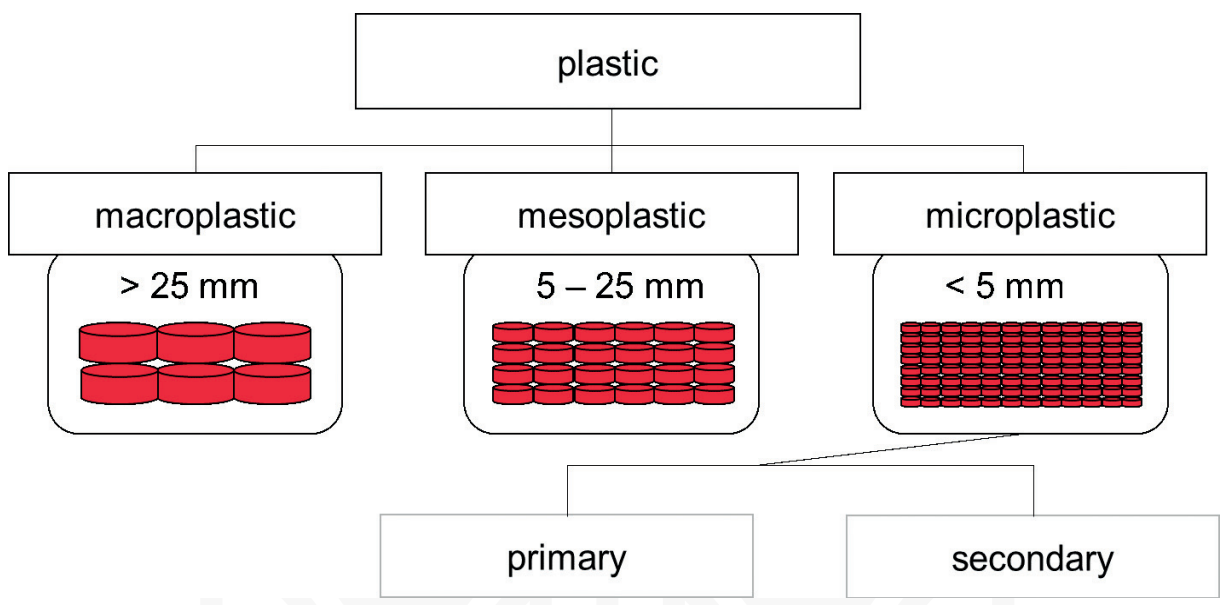

Fig. 1. Classification of plastic in the aquatic environment [8]

Microplastics occur in the aquatic environment as primary and secondary micropastic particles. Primary microplastic describes industrial defined and produced particles. They include for example pellets, which are used as basic material in the production of plastic products. [9] Another application is to use the microbeads as filler for cosmetics or as abrasives in toothpaste and peeling. To estimate the emission of microplastics from domestic wastewater the TU Berlin conducted panel tests. A group of customers (approx. 20 people) documented the usage and the volume of all critical products. For these tests primary microplastics from shampoo (Fig. 2a), peeling (Fig. 2b) and toothpaste (Fig. 2c) were separated and balanced out. The proportions of the particles are shown in Figure 2.

For the input of microplastics raised by the named products from domestic wastewater an amount of approximately $7.5 \mathrm{~g} /($ person $\cdot \mathrm{a})$ was determined [10].
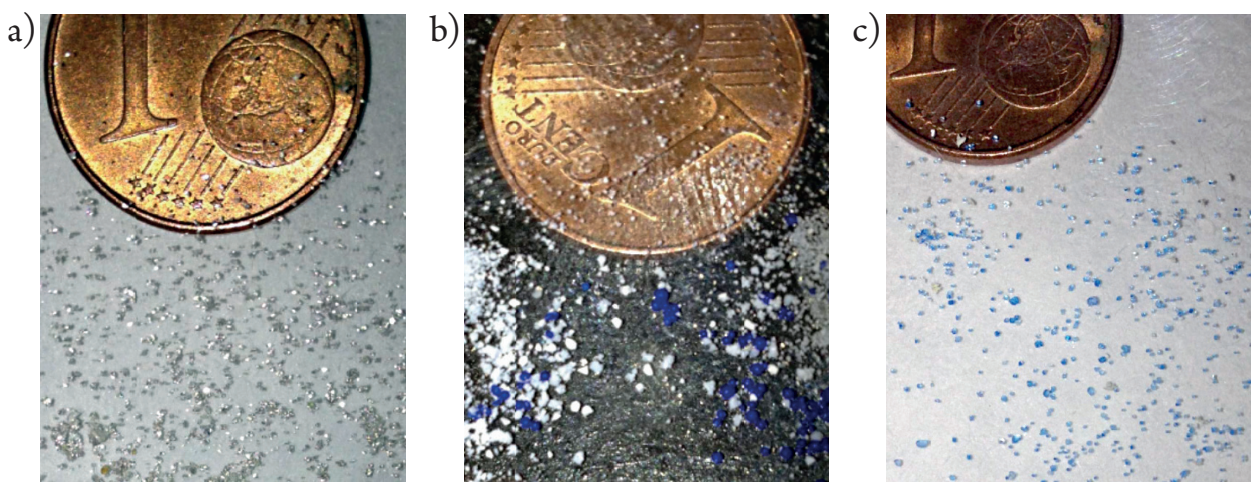

Fig. 2. Microplastics from shampoo (a), peeling (b), toothpaste (c) [10] 
a)

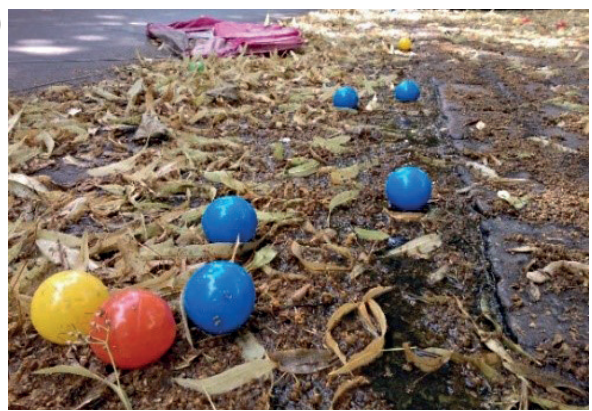

b)

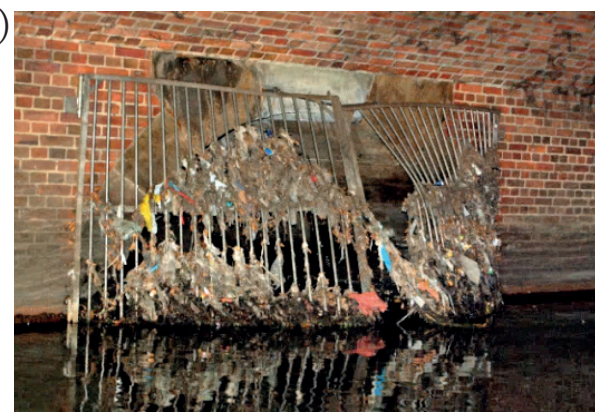

Fig. 3. Plastic in rainwater runoff (a) and mixed sewage water (b) in Berlin

Secondary microplastic describes fragments or fibers which rise by biological, chemical or physical degradation of sizeable particles [9]. Consequently, microplasticparticles occur in different size, form and colour. Figure 3 shows macroplastics in the effluent of rainwater runoff (Fig. 3a) and in a mixed sewage water system (Fig. 3b) which could end up as grinded microplastics in the aquatic environment.

\section{Microplastics in the aquatic environment}

Plastic debris in the aquatic ecosystem amount to $80 \%$ of the total waste [11]. Because of its low density and its durability plastic is transported over wide distance by the rivers and the wind [12] so that it has been found on isolated islands, the Arctic and Antarctic zone [13]. Two big garbage patches developed in the North Pacific and the North Atlantic Ocean. The great Pacific garbage patch, which was discoverded in 1997 is approximatly as big as central Europe and it is estimated to contain 1 million plastic particles and parts per square kilometer [11]. Except for the garbage patches, microplastics are urbiquitary in the aquatic environment, which has been indicated in scientific studies in the recent past $[14,6]$.The plastic debris in the oceans increased to $80 \%$ from land $[7,15]$. A reasonable part is transported by rivers to the oceans however only a few studies have been conducted $[16,17]$.

The consequences of the urbiquitary plastic load on the aquatic ecosystem is diverse; in comparison to natural flotsam such as wood; the plastic parts and particles can act as carriers, which can transport attached organisms over wide distances far away from their geographical origin. The introduced organisms may suppress the native species and influence or change the ecosystem [18].

In 2012 an interaction between plastic debris in the ocean was registered with 663 marine animal species, this discribes an increase of $40 \%$ in comparison to the year 1997. In more than $50 \%$ of the cases living organism become entangled to the debris or they absorb them. Meanwhile, different kinds, forms and sizes of plastic particles are found meanwhile in stomachs of mammals, fishes and birds [19].

Planktivorus animals ingest microplastics with their nourishment beside microplastics was verified in shrimps, which absorbed zooplankton with microplastics [20] and in mussels which transferred microplastics to crabs [21]. 
In this manner microplastics could enter the food chain and spread in the food web $[22,23,24]$. Absorbed microplastics can have different effects. Experiments with mussels showed that microplastics accumulate in the mussel and cause inflammatory changes of the cells [11]. Especially because the experiment was performed under conditions with high microplastic concentrations. It is yet to be verified up to what extend the results are transferable in the environment [5].

Often non - digestible plastic particles are not excreted, so that the animals starve with stuffed stomach. Sharp edged particles may harm the mucosa of the animals. In addition to the mechanical characteristics microplastic particles may transport harmful substances like plasticizer or adsorbed persistant substances. They possibly escape from the plastic in the alimentary canal and have an effect on the organism. Some of them are carcinogenic or mutagenic or they can affect the hormonal balance [11].

Currently, coherent toxicology methods for the evaluation of microplastics (especially for particles with few $\mu \mathrm{m}$ ) are missing.

\section{Microplastics in Urban Water Management}

Figure 4 indicates that the different pathways of microplastics are complex although a balancing of the pathways has not been performed so far. Decreasing microplastic particle concentrations have been verified over the treatment stations of a wastewater treatment plant (WWTP) and in the ocean [25]. The plastic tyre wear particles are assumed to be

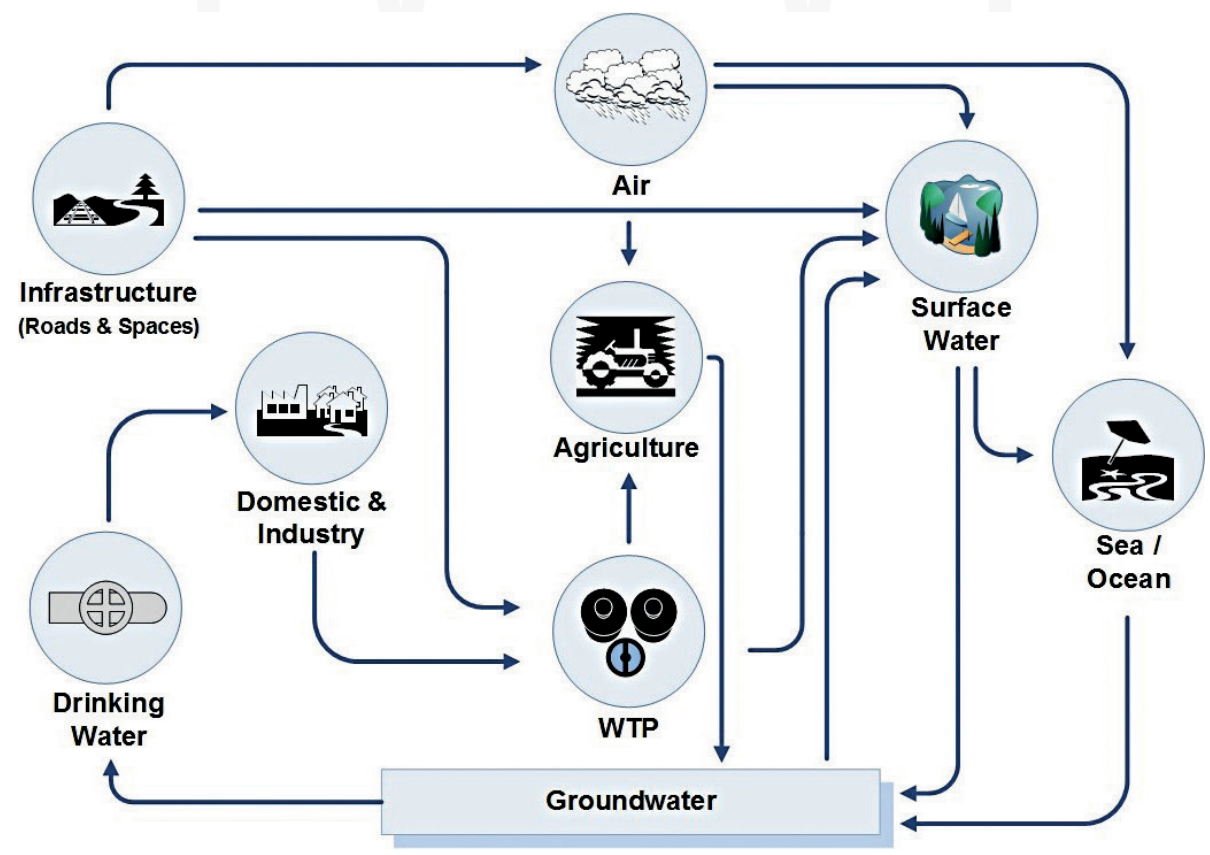

Fig. 4. Pathways of microplastics in the aquatic environent 
a part of the fine particulate matter and the rain water runoff. Furthermore, the consumption of private households and the usage in industrial production processes may contribute microplastic particles to the aquatic environment.

In urban water management microplastics can get to the aquatic environment through the following pathways in principal :

1. If microplastics are not restrained sufficiently in wastewater treatment

2. By combined wastewater overflow

3. By discharging rainwater runoff

Currently, only a few studies about the microplastic exposure and -removal in WWTP are available. New studies in Finnland, Germany, Russia, Austria, Sweden and USA found different quantities of microplastics in the purification process of the WWTP. The results differ widely in terms of validity and resilience, because different techniques of sampling, preparation and analytical equipment was used as shown in Table 2 .

Table 2. Microplastics at the effluent of wastewater treatment plants (WWTP)

\begin{tabular}{|c|c|c|c|c|}
\hline Location & $\begin{array}{l}\text { Sample } \\
\text { volume }\end{array}$ & Sampling equipment & Particle/1 & $\begin{array}{l}\text { Analytical } \\
\text { equipment }\end{array}$ \\
\hline $\begin{array}{l}\text { WWTP } \\
\text { in Finland [25] }\end{array}$ & $2-2851$ & $\begin{array}{c}\text { filtertube: } \\
\varnothing=60 \mathrm{~mm} \\
\text { mesh size: } \\
20 \mu \mathrm{m}, 100 \mu \mathrm{m}, 200 \mu \mathrm{m}\end{array}$ & $\begin{array}{l}8.6 \pm 2,5 \text { particles } \\
4.9 \pm 1,4 \text { fibres }\end{array}$ & optical microscope \\
\hline $\begin{array}{l}12 \text { WWTPs } \\
\text { in Germany } \\
{[26]}\end{array}$ & $390-10001$ & $\begin{array}{l}\text { sieve with mesh size: } \\
\qquad 500 \mu \mathrm{m} \\
\text { stainless steel candle filter } \\
\text { with mesh size: } \\
10 \mu \mathrm{m}\end{array}$ & $\begin{array}{l}0.077-0.712(8.851) \\
(\text { particles }<500 \mu \mathrm{m}) \\
0-0.052 \\
(\text { particles }>500 \mu \mathrm{m}) \\
0.098-4.808 \text { (fibers) }\end{array}$ & $\begin{array}{l}\text { optical microscope, } \\
\text { ATR - FTIR* } \\
\text { micro - FTIR }\end{array}$ \\
\hline $\begin{array}{l}\text { WWTP } \\
\text { in Russia } \\
\text { [27] }\end{array}$ & 81 & $\begin{array}{c}\text { filtertube: } \\
\emptyset=60 \mathrm{~mm} \\
\text { mesh size: } \\
20 \mu \mathrm{m}, 100 \mu \mathrm{m}, 300 \mu \mathrm{m}\end{array}$ & $\begin{array}{l}16 \text { fibrous } \\
7 \text { synthetic } \\
125 \text { black }\end{array}$ & optical microscope \\
\hline $\begin{array}{l}\text { WWTP } \\
\text { in Austria } \\
{[28]}\end{array}$ & 200001 & $\begin{array}{l}\text { sieve batch with } 3 \text { sieves } \\
\text { mesh size: } \\
63 \mu \mathrm{m}, 630 \mu \mathrm{m}, 5 \mathrm{~mm}\end{array}$ & $\begin{array}{l}\text { Less than } 0.001 \\
(\text { particles }>63 \mu \mathrm{m})\end{array}$ & optical microscope \\
\hline $\begin{array}{c}\text { WWTP } \\
\text { in Sweden } \\
{[29]}\end{array}$ & 10001 & $\begin{array}{l}\text { filter holder/net: } \varnothing= \\
\qquad 80 \mathrm{~m} \\
\text { mesh size: } 300 \mu \mathrm{m}\end{array}$ & $\begin{array}{l}3.75 \pm 1.25 \text { fragments } \\
0.5 \pm 0.5 \text { flakes } \\
4 \pm 0.58 \text { fibers } \\
(\text { particles } \geq 300 \mu \mathrm{m})\end{array}$ & $\begin{array}{c}\text { optical microscope, } \\
\text { ATR - FTIR }\end{array}$ \\
\hline $\begin{array}{l}7 \text { WWTPs } \\
\text { in USA [30] }\end{array}$ & $\begin{array}{c}189000- \\
-95700001\end{array}$ & $\begin{array}{c}\text { stack of } 3(4) \text { sieves } \\
\text { mesh size: }(20 \mu \mathrm{m}), \\
45 \mu \mathrm{m}, 180 \mu \mathrm{m}, 400 \mu \mathrm{m} \\
\text { surface skimmer with } \\
\text { mesh size: } \\
125 \mu \mathrm{m}\end{array}$ & $\begin{array}{l}0 \text { particles } \\
0 \text { fibers } \\
\left(3.12^{*} 10^{-7}-2.43^{*} 10^{-6}\right) \\
\text { particles skimmed }\end{array}$ & optical microscope \\
\hline
\end{tabular}

${ }^{*}$ ATR-FTIR: Attenuated Total Reflectance- Fourier Transformed Infrared 
The studies refer to sample volumes of WWTP -effluent from 2 up to $9570000 \mathrm{l}$, the filtration process is performed with mesh size from $10 \mu \mathrm{m}$ up to $5 \mathrm{~mm}$ and for taking the samples measuring cups are taken as well as different pumps at the same time [25, 26, $27,28,29,30]$. Mintening et al. reveals that the method for taking the samples as well as the preparation of the samples may affect the contamination of the sample with microplastics by the atmosphere and laboratory equipment significantly. Fourier Transformed Infrared (FTIR) is widely prefered for analysing microplastic particles. It allows for the determination of the type of plastic after the sample has been prepared [26]. The number of particles can be counted whereas the mass can not be determined because the FTIR focuses on the material.

To estimate the weight percent of microplastics which may summed up in the effluent of WWTP the following contemplation is made:

The particles are spherical, have an average size of $1000 \mu \mathrm{m}$ and consist of mostly utilized plastic PE. From the maximum concentration of $0.712 \mathrm{pcs} / \mathrm{l}$, which is described for the German WWTPs in Table 2, results a weight percent of microplastics of $0.34 \mathrm{mgTSS} / \mathrm{l}$.

Making an assumption that $12 \mathrm{mg}$ TSS/1 is the average mass of suspended solids at the effluent of a WWTP, the plastic fraction would sum up at least $3 \%$ and could be neglected related to the mass. However, a distribution of the particle size does not exist.

A benchmark for technologies of advanced wastewater treatment with the focus on microplastics has not been formulated yet. In an first measurement Mintening et al. 2014 determined for the final filtration, where cloth filtration media is installed, a reduction of $97 \%$ of microplastics. In the whole purification process of the WWTP in Russia, Talvitie et al. determined a quantity reduction of $96 \%$ for microplastics and for the whole purificaton process of the Swedish WWTP Magnusson et al. determined a reduction of 99,9\% for the American WWTPs Carr et al. suggests that the effluent discharges of microplastics are minimal. Current studies emanate from significant amounts of microplastic particles remaining in the sluge [26, 29].There is a further need of research for this fraction to get verifiable results. Concerning the entry from combined wastewater overflow and discharged rainwater runoff currently there is no data available. In addition, for raw sewage any valid concentrations are identified so that the degree of degradation for microplastics can just be estimated.

\section{Conclusions}

The first studies about microplastics in wastwater treatment plans suggest that the restrained grade of microplastic particles during the purification process is considerable.

To evaluate the particles at the effluent of a WWTP as a basis of deciding whether or not to implement advanced wastewater treatment is mainly depending on the ecological relevance of the particles (size, mass, number, etc.) which is not fully clarified.

Technical solutions for the effluent of WWTPs and for combined wastewater overflow, could be the istallation of additional processes like for example micro sives, cloth filtration and sand filtration, which separate particles, specificly microplastics. In terms of this technologies, high performance webs and the cloth filtration media are promising solutions. 
To separate microplastics form rainwater runoff decentralized systems could be implemented in road gullys at relevant sites. The different technics are currently evaluated in practical investigations (-OEMP-Optimized materials and processes for the separation of microplastic form the water cycle, BMBF-funded).

Plastics and microplastics will be preserved in the environment for many years, therefore systematic studies in the field of urban water management are reasonable and the municipality, the industry, the research and the citizen/consumer are requested to collaborate.

\section{References}

[1] Strong A.B., Plastics: Materials and Processing, 3 edition, Prentice Hall, New Jersey 2006.

[2] Braun D., Kleine Geschichte der Kunststoffe, Carl Hanser Verlag, München 2013.

[3] Statista, Weltweite und europäische Produktionsmenge von Kunststoff in den Jahren 1950 bis 2014 (in Millionen Tonnen), http://de.statista.com/statistik/daten/studie/167099/ umfrage/weltproduktion-von-kunststoff-seit-1950/ (access: 18.04.2016).

[4] Consultic Marketing \& Industrieberatung GmbH 63755 Alzenau Germany, Produktion, Verarbeitung und Verwertung von Kunststoffen in Deutschland 2015 - Kurzfassung, http://www.plasticseurope.de/Document/studie-zu-produktion-verarbeitung-undverwertung-von-kunststoffen-in-deutschland-2013---kurzfassung-aspx?FolID=2 (access: 25.11.2016).

[5] Bannick C.G., Brand K., Jekel M., König F., Miklos D., Rechenberg B., Kunststoffe in der Umwelt, article in Korrespondenz Abwasser, vol. 62 (1), 2015, 34-39.

[6] Sul J., Costa M., The present and future of microplastic pollution in the marine environment, Environmental Pollution, 185, 2014, 352-364.

[7] Andrady A.L., Microplastics in the marine environment, Marine Pollution Bulletin, 62, No. 8, 2011, 596-1605.

[8] Essel R., Engel L., Carus M., Ahrens R.H., Quellen für Mikroplastik mit Relevanz für den Meeresschutz in Deutschland, Text 63/2015 UBA, http://www.umweltbundesamt.de/ publikationen/quellen-fuer-mikroplastik-relevanz-fuer-den (access: 18.04.2016).

[9] Hidalgo-Ruz V., Gutow L., Thompson R.C., Thiel M., Microplastics in the Marine Environment: A Review of the Methods Used for Identifcation and Quantifcation, Environmental Science \& Technology, 46, No. 6, 2012, 3060-3075.

[10] Feller L., Bilanzierung von Mikroplastik in Haushaltsabwasser, Bachelor Thesis im bachelor degree course civil engineering at the department Siedlungswasserwirtschaft at the TU Berlin, release 25.02.2015, first supervisor: Barjenbruch Matthias, second supervisor Venghaus Daniel.

[11] Holm P., Schulz G., Athanasopulu K., Meeresverschmutzung der neuen Art: Mikroplastik - ein unsichtbarer Störnfried, Biologie unserer Zeit, 43, No. 1, 2013, 27-33.

[12] Hammer J., Kraak M.H., Parsons J.R., Plastics in the marine environment: The dark side of a modern gift, Reviews of Environmental Contamination and Toxicology, 220, 2012, 1-44. 
[13] Lubbadeh J., Der junge Mann und das Meer, Technology Review, No. 7, 2014, 26-33.

[14] Cole M., Lindeque P., Halsband C., Galloway T.S., Microplastics as contaminants in the marine environment: A review, Marine Pollution Bulletin, 62, No. 12, 2011, 2588-2597.

[15] Wagner M., Scherer C., Alvarez-Muñoz D., Brennholt N., Bourrain X., Buchinger S., Fries E., Grosbois C., Klasmeier J., Marti T., Rodriguez-Mozaz S., Urbatzka R., Vethaak A., Winther-Nielsen M., Reifferscheid G., Microplastics in freshwater ecosystems: What we know and what we need to know, Environmental Sciences Europe, 26, 12, 2014, DOI:10.1186/s12302-014-0012-7.

[16] Moore C.J., Lattin G.L., Zellers A.F., Quantity and type of plastic debris flowing from two urban rivers to coastal waters and beaches of Southern California, Journal of Integrated Coastal Zone Management, 11, No. 1, 2011, 65-73.

[17] Rech S., Macaya-Caquilpán V., Pantoja J.F., Rivadeneira M.M., Jofre Madariaga D., Thiel M., Rivers as a source of marine litter. A study from the SE Pacific, Marine Pollution Bulletin, 82, No. 1-2, 2014, 66-75.

[18] Gregory M.R.,Environmental implications of plastic debris in marine settings-entanglement, ingestion, smothering, hangers-on, hitch-hiking and alien invasions, Philosophical Transactions of the Royal Society, B: Biological Sciences, 364, 2009, 2013-2025.

[19] Umweltbundesamt, Auswirkungen von Meeresmüll., http://www.umweltbundesamt.de/ sites/default/files/medien/419/dokumente/auswirkungen_von_meeresmuell.pdf, Version: 2013 (access: 18.04.2016).

[20] Setälä O., Fleming-Lehtinen V., Lehtiniemi M., Ingestion and transfer of microplastics in the planktonic food web, Environmental Pollution, 185, 2014, 77-83.

[21] Farell P., Nelson K., Trophic level transfer of microplastic: Mytilus edulis (L.) to Carcinus maenas (L.), Environmental. Pollution, 177, 2013, 1-3.

[22] Wright S.L., Thompson R.C., Galloway T.S., The physical impacts of microplastics on marine organisms: A review, Environmental Pollution, 178, 2013, 483-492.

[23] Miranda D.d.A., de Carvalho-Souza G.F., Are we eating plastic-ingesting fish?, Marine Pollution Bulletin, 103, 2016, 109-114.

[24] Rochman C.M., Tahir A., Williams S.L., Baxa D.V., Lam R., Miller J.T., Teh F.C., Werorilangi S., Teh S.J., Anthropogenic debris in seafood: Plastic debris and fibers from textiles in fish and bivalves sold for human consumption, Scientific Reports, 5, 14340, 2015, DOI:10.1038/srep14340.

[25] Talvitie J., Heinonen M., Paakkonen J.P., Vahtera E., Mikola A., Setala O., Vahala R., Do wastewater treatment plants act as a potential point source of microplastics? Preliminary study in the coastal Gulf of Finland, Baltic Sea, Water Science Technologie, 72(9), 2015, 1495-1504, DOI:10.2166/wst.2015.360.

[26] Mintening S., Int-Veen I., Löder M., Gerdts G., Mikroplastik in ausgewählten Kläranlagen des Oldenburgisch Ostfriesischen Wasserverbandes (OOWV) in Niedersachsen.Probenanalyse mittels Mikro-FTIR Spektroskopie. Abschlussbericht, http://www.awi.de/fileadmin/ user_upload/News/Press_Releases/2014/4_Quartal/Mikroplastik_Klaeranlagen/ Abschlussbericht_Mikroplastik_in_Klaeranlagen.pdf (access: 18.04.2016). 
[27] Talvitie J., Heinonen M., HELCOM 2014 - Base project 2012-2014: Preliminary study on synthetic microfibers and particles at a municipal wastewater treatment plant, http://www.helcom.fi/Lists/Publications/Microplastics at a municipal waste water treatment plant.pdf (access: 18.04.2016).

[28] Kreuzinger N., Mikroplastik in der aquatischen Umwelt. Die Rolle der Kläranlage, presentation of the Technischen Universität Wien, Institut für Wassergüte, Ressourcenmanagement und Abfallwirtschaft, Wien 2014.

[29] Magnuson K., Norén F., Screening of microplastic particles in and down-stream a wastewater treatment plant, http://www.diva-portal.org/smash/get/diva2:773505/ FULLTEXT01.pdf (access: 18.04.2016).

[30] Carr S.A., Liu J., Tesoro A.G., Transport and fate of microplastic particles in wastewater treatment plants, Water Research, 91, 2016, 174-182, http://dx.doi.org/10.1016/j. atres.2016.01.002. 